\title{
IMPLEMENTASI KEBIJAKAN PENANGANAN EMISI GAS BUANG DI KABUPATEN BANDUNG
}

\author{
Ade Ridwan' ${ }^{1}$, Heru Nurasa ${ }^{2}$, Mas Halimah ${ }^{3}$ \\ ${ }^{1,2,3}$ Program Pascasarjana Kebijakan Publik \\ Fakultas Ilmu Sosial dan Ilmu Politik \\ Universitas Padjadjaran \\ aderidwan8685@gmail.com
}

\begin{abstract}
ABSTRAK
Pelaksanaan pengujian emisi gas buang pada kendaraan bermotor diperoleh gejala-gejala berdasarkan observasi bahwa pelaksanaan uji emisi gas buang di Kabupaten Bandung sangat jarang dilakukan, banyaknya kendaraan bermotor jika diamati mengeluarkan asap dari knalpotnya yang menandakan tingginya pencemaran udara, dan uji emisi gas buang hanya dilaksanakan pada kendaraan tertentu khususnya berkaitan dengan emisi gas buang yang sudah memasukkan prosedur pengujian emisi gas buang kendaraan.

Berdasarkan fenomena tersebut, tujuan penelitian ini yaitu untuk menganalisis dan mengetahui implementasi kebijakan penanganan emisi gas buang yang dilakukan Dinas Perhubungan Kabupaten Bandung. Teori yang digunakan sebagai pedoman penelitian adalah teori implementasi kebijakan. Sesuai dengan karakteristik penelitian, pendekatan penelitian ini menggunakan studi metode penelitian kualitatif dengan desain deskriptif objek penelitian di dinas Perhubungan Kabupaten Bandung, adapun pengumpulan data dilakukan adalah studi kepustakaan dan studi lapangan seperti observasi dan wawancara. Sementara pengumpulan data sekunder dilakukan pengolahan literatur, dokumen, perundang-undangan serta hasil penelitian terdahulu. Analisis data yang digunakan adalah triangulasi data hasil wawancara serta membandingkan wawancara dengan isi dokumen yang berkaitan.

Kata kunci: Implementasi Kebijakan,Emisi , Gas Buang
\end{abstract}

\begin{abstract}
The implementation of exhaust emission testing in motorized vehicles shows symptoms based on the observation that the implementation of exhaust emission tests in Bandung Regency is very rarely carried out, the number of motorized vehicles that when observed emits smoke from their exhausts which indicates high air pollution, and exhaust emission tests are only carried out in certain vehicles, in particular with regard to exhaust gas emissions that have included the vehicle exhaust emission testing procedure.

Based on this phenomenon, the purpose of this study is to analyze and determine the implementation of exhaust gas emission management policies carried out by the Bandung Regency Transportation Agency. The theory used as a research guide is the theory of policy implementation. In accordance with the characteristics of the research, this research approach uses qualitative research methods with descriptive design, while data collection is carried out in the form of library research and field studies such as observations and interviews. Meanwhile, secondary data collection is carried out by processing literature, documents, legislation and the results of previous research. The data analysis used was triangulation of interview data and comparing interviews with the contents of related documents.
\end{abstract}

Key word: Policy Implementation, Emissions, and Exhaust Gas

\section{PENDAHULUAN}

Emisi gas buang kendaraan bermotor merupakan penyumbang terbesar terjadinya pencemaran udara. Pencemaran udara terjadi jika udara di atmosfer dicampuri dengan zat atau radiasi yang berpengaruh buruk terhadap organisme hidup. Pencemaran udara merupakan masalah yang sangat penting untuk diatasi karena dapat mengurangi kadar oksigen 
dalam udara yang dapat mempengaruhi gangguan pernafasan. Seiring dengan semakin banyaknya kendaraan bermotor bakar di kotakota besar seluruh Indonesia pencemaran udarapun semakin naik.

Hal ini perlu mendapat perhatian lebih dari berbagai pihak untuk mengurangi pencemaran udara tersebut. Kendaraan bermotor merupakan alat transportasi darat yang digerakkan oleh peralatan tehnik. Alat transportasi darat dengan menggunakan mesin ini sering dikenal dengan mobil dan motor. Kendaraan bermotor menggunakan mesin pembakaran dalam, digerakkan oleh manusia dan menggunakan bahan bakar minyak atau tenaga alam. Kendaraan bermotor di Indonesia meningkat jumlahnya dari tahun ke tahun, gas buang yang di timbulkan dari kendaraan bermotor tersebut menimbulkan polusi udara sebesar 70 sampai 80 persen, sedangkan pencemaran udara akibat industri hanya 20-30 persen saja.

Dinas perhubungan Kabupaten Bandung Belum adanya peraturan yang tegas mengenai emisi gas buang, maka seiring dengan pertambahan jumlah kendaraan bermotor, pencemaran udara di Kabupaten Bandung juga akan semakin meningkat. Polusi udara ini sudah merupakan masalah yang meresahkan masyarakat, karena dampak dari polusi udara ini sangat berbahaya bagi kesehatan. Perjalanan suatu kendaraan tentunya akan menimbulkan polusi terhadap sekitarnya, apalagi jika kendaraan tersebut tidak pernah dilakukan pemeriksaan emisi gas buang secara berkala, dapat menimbulkan polusi yang mencemari membahayakan terhadap manusia, hewan, tumbuhan, air dan udara sekitarnya. Emisi kendaraan selain dapat mencemari udara juga dapat menjadi pertanda bahwa mesin kendaraan mengalami pembakaran yang tidak sempurna sampai terjadinya kerusakan. Baik kerusakan pada bagian dalam maupun kerusakan bagian luar yang diakibatkan kurang sempurnanya pembakaran.

Kewajiban uji emisi yang diberlakukan menjadi persyaratan bagi pemilik kendaraan bermotor untuk melakukan perpanjangan STNK (Surat Tanda Nomor Kendaraan Bermotor), tanda bukti uji lulus uji emisi harus dilampirkan. Hal tersebut tertulis pada Peraturan daerah Nomor 09 Tahun 2012 pasal
11 ayat 3 :

"Setiap pemilik kendaraan yang melakukan perpanjangan STNK bermotor harus melampirkan tanda bukti lulus uji emisi gas buang kendaraan bermotor”. Selanjutnya, uji emisi juga dijadikan syarat teknis laik jalan untuk kendaraan khusus alat berat, angkutan beban dan angkutan umum pada proses pengujian kendaraan bermotor atau uji kir.

Dalam pelaksanaannya, kebijakan uji emisi yang diatur dalam Peraturan Daerah Nomor 09 Tahun 2012 ini ternyata masih dijumpai berbagai masalah. Sebagaimana hasil informasi yang didapat, masih banyak kendaraaan bermotor yang belum mengikuti uji emisi. Hal tersebut dapat dilihat pada tabel jumlah kendaraan bermotor roda dua dan roda empat yang mengikuti uji emisi gas buang kendaraan tahun 2017 sampai dengan 2019 sebagai berikut :

Tabel 1.1

Laporan Kendaraan Wajib Uji Di dinas Perhubungan Kabupaten Bandung Tahun 2017-2019

\begin{tabular}{|c|c|r|}
\hline TAHUN & TARGET & REALISASI \\
\hline 2017 & 51.375 kendaraan & $\begin{array}{r}44.159 \\
\text { kendaraan }\end{array}$ \\
\hline 2018 & 44.277 kendraan & $\begin{array}{r}42.439 \\
\text { kendaraan }\end{array}$ \\
\hline 2019 & 55.220 kendaraan & $\begin{array}{r}25.359 \\
\text { kendaraan }\end{array}$ \\
\hline
\end{tabular}

Sumber: Kantor Dinas Perhubungan Kabupaten Bandung Tahun 2019,

Berdasarkan tabel tersebut diketahui bahwa jumlah kendaraan yang wajib uji emisi gas buang berbanding lurus dengan jumlah realisasi uji kendaraan bermotor dana pada Dinas perhubungan Kabupaten Bandung Tahun 2017-2019, dimana kendaraan yang wajib uji untuk setiap tahun mengalami peningkatan. Menurut data terakhir dari pertumbuhan pasar penjualan kendaraan baru untuk roda empat naik hampir $25 \%$ pertahunnya.Sedangkan di Kabupaten Bandung jumlah kendaraan bermotor sebanyak 55.220 unit, terdiri atasunit unit kendaraan roda empat atau lebih. Jika 


\begin{tabular}{|c|c|c|c|}
\hline $\mathrm{NO}$ & $\begin{array}{c}\text { JENIS } \\
\text { KENDARAAN } \\
\text { BERMOTOR }\end{array}$ & JENIS & $\begin{array}{c}\text { BESARAN } \\
\text { (RP) }\end{array}$ \\
\hline 1 & Mobil pribadi & $\begin{array}{c}\text { Administrasi } \\
\text { Jasa Pengujian } \\
\text { Stiker Lulus } \\
\text { Uji } \\
\text { Surat } \\
\text { Keterangan } \\
\text { Uji Emisi }\end{array}$ & Rp .50.000,- \\
\hline 2 & $\begin{array}{c}\text { Kendaraan } \\
\text { Wajib uji }\end{array}$ & $\begin{array}{c}\text { Administrasi } \\
\text { Jasa Pengujian } \\
\text { Stiker Lulus } \\
\text { Uji } \\
\text { Surat } \\
\text { Keterangan } \\
\text { Uji Emisi }\end{array}$ & Rp. 40.000,- \\
\hline 3 & Sepeda Motor & $\begin{array}{l}\text { Administrasi } \\
\text { Jasa Pengujian } \\
\text { Stiker Lulus } \\
\text { Uji } \\
\text { Surat } \\
\text { Keterangan } \\
\text { Uji Emisi }\end{array}$ & Rp. 50.000,- \\
\hline
\end{tabular}

diasumsikan kendaraan yang berjalan selama 16 jam sejumlah 0.5 \% saja berarti ada 2186 unit kendaraan bermotor dengan pemakaian bahan bakar minyak bensin/solar rata-rata 1:10 dengan kecepatan rata-rata $40 \mathrm{~km} / \mathrm{jam}$ menghabiskan BBM 139.904 liter perhari. Pemakaian sebanyak 139.904 liter BBM yang teroksidasi dengan oksigen (O2) akan mengeluarkan gas emisi 0.44 ppm CO 2, 37 ppm CO,3.7 ppm NOx, 2.8 ppm SOx, dan 6.7 ppm HidroKarbon (HC) yang termasuk dalam kategori mengganggu pernafasan.

Kabupaten Bandung saat ini dalam menjalankan uji emisi gas buang masih belum efektif yang diduga kurangnya sosialisasi dan profesionalisme dalam pelaksanaannya dimana kendaraan wajib uji emisi gas buang mengalami peningkatan setiap tahunnya. Berdasarkan data pengujian yag ada emudian, guna meningkatkan kemampuan dalam bidang pendanaan untuk pembangunan, penyelenggaraan pengujian ini juga sekaligus menjadi potensi untuk menambah pundi-pundi PAD Kabupaten Bandung. Karena setiap kendaraan yang melalukan uji emisi dikenakan biaya yang telah di atur dalam Peraturan Daerah No 6 Tahun 2014 tentang Retribusi Pengujian Kendaraan Bemotor. Besaran biaya dapat dilihat di tabel dibawah ini :

\section{Tabel 1.2}

Besaran Biaya Uji Emisi Gas Buang Sumber : UPT PKB Dinas Perhubungan Kab. Bandung , 2020

Dengan perkembangan volume kendaraan yang meningkat, Kabupaten Bandung memiliki potensi besar untuk menggali pendapatan asli daerah dari pelaksanaan uji emisi gas kendaraan tersebut. Namun, sejak diberlakukannya wajib uji emisi bagi kendaraan bermotor, UPT. Pengujian Kendaraan Bermotor belum mampu mencapai target retribusi dari sektor tersebut yang telah ditetapkan oleh pemerintah, khususnya dari jenis kendaraan bermotor roda dua dan roda empat. Padahal potensi dari dua jenis kendaraan tersebut sangat besar mengingat jumlahnya yang banyak. Besaran target dan realisasi retribusi tersebut dapat dilihat dari tabel berikut :

Tabel 1.3

Retribusi Uji Emisi Gas Buang Kendaraan Roda 2 dan Roda 4 Tahun 2018 dan 2019

\begin{tabular}{|c|c|c|}
\hline \multirow{2}{*}{ Kegiatan } & \multicolumn{2}{|c|}{ TAHUN } \\
\cline { 2 - 3 } & 2018 & 2019 \\
\hline TARGET & 335.125 .000 & 750.000 .000 \\
\hline REALISASI & 320.000 & 17.150 .000 \\
\hline PERSENTASI & $\mathbf{0 . 0 9} \%$ & $2.29 \%$ \\
\hline
\end{tabular}

Sumber : UPT PKB Dinas Perhubungan Kab.

Bandung ,2020

Berdasarkan tabel di atas, bisa dilihat dari tahun ke tahun realisasi retribusi uji emisi gas buang kendaraan pada sektor roda dua dan roda empat tidak pernah mencapai target, pada tahun 2018 realisi sangat jauh dari target yang telah ditetapkan, realiasinya hanya Rp. 320.000 dari total target yang telah ditetapkan sebesar Rp. 335.125.000. Begitu juga pada tahun 2019 yang telah di targetkan sebesar Rp. 750.000 .000 namun realisasinya hanya $\mathrm{Rp}$. 17.150.000, padahal potensi retribusi uji.

Berdasarkan tabel di atas, bisa dilihat dari tahun ke tahun realisasi retribusi uji emisi gas buang kendaraan pada sektor roda dua dan roda empat tidak pernah mencapai target, pada tahun 2018 realisi sangat jauh dari target yang telah ditetapkan, realiasinya hanya Rp. 
320.000 dari total target yang telah ditetapkan sebesar Rp. 335.125.000. Begitu juga pada tahun 2019 yang telah di targetkan sebesar Rp. 750.000.000 namun realisasinya hanya Rp. 17.150.000, padahal potensi retribusi uji emisi dari sektor tersebut bisa di maksimalkan hingga Rp 4 miliar.

Mengenai hal itu, kepala UPT. PKB dari Dinas Perhubungan kabupaten Bandung tahun 2019 mengatakan hal tersebut disebabkan oleh keterlibatan dan kesadaran masyarakat pengguna kendaraan bermotor roda dua dan roda empat untuk mengikuti uji emisi masih rendah. Rendahnya keterlibatan masyarakat untuk melakukan uji emisi pada kendaraan mereka tersebutlah yang mengakibatkan tidak tercapainya target retribusi yang telah ditetapkan tiap tahunnya.

Adapun dampak negatif dari emisi gas buang dari kendaraan-kendaraan yang tidak memenuhi ambang batas emisi dapat menyebabkan beberapa gejala yang menyebabkan penyakit, diantaranya :

Tabel .1.4

Dampak terhadap Emisi Gas Buang Yang tidak Memenuhi Ambang Batas

\begin{tabular}{|c|l|}
\hline no & $\begin{array}{c}\text { Dampak terhadap Emisi Gas Buang } \\
\text { Yang tidak Memenuhi Ambang Batas }\end{array}$ \\
\hline 1 & Pemicu Hipertensi \\
\hline 2 & Penyebab Iritasi Mata \\
\hline 3 & Penurunan Kecerdasan Otak \\
\hline 4 & Menggangu perkembangan mental anak \\
\hline 5 & Tenggorokan gatal dan batuk-batuk \\
\hline 6 & Mengurangi fungsi reproduksi laki-laki \\
\hline
\end{tabular}

Sumber dari : Dinas kesehatan Kabupaten Bandung tahun , 2020

Gejala-gejala tersebut di atas sangat merugikan pada kesehatan manusia, serta berdampak negatif pula terhadap hewan, air, udara dan pencemaran lingkungan lainnya.

Oleh karena itu, uji emisi tersebut di atas seyogyanya terus diupayakan dan disosialisasikan oleh Pemerintah, aparat penegak hukum dan masyarakat antara lain dengan menyisir kendaraan-kendaraan yang belum memeriksakan uji gas buang supaya sadar memeriksakan emisi gas buangnya ke tempat-tempat yang telah ditentukan untuk meminimalisir dampak negatif yang akan ditimbulkan dari kendaraan tersebut.

Upaya lain yang dapat dilakukan untuk mendukung suksesnya program emisi gas buang terhadap kendaraan-kendaraan di Kabupaten Bandung adalah dilakukannya Pengawasan Langsung oleh Kepala UPT PKB Dinas Perhubungan Kabupaten Bandung dalam pelaksanaan pemeriksaan emisi gas buang pada kendaraan-kendaraan yang akan diuji emisi gas buang, sehingga hal-hal yang perlu diteliti dan disampaikan terhadap detail kendaraan yang dapat memengaruhi ambang batas emisi gas buang dapat tersosialisasikan dengan efektif bersama-sama dengan pemilik dan atau pengguna kendaraan tersebut di atas.

1. Pelaksanaan uji emisi gas buang di Kabupaten Bandung secara praktis masih belum efektif masih jauh dari realiasasi pelaksanaannya, berdasarkan data masih jauh target

DATA KENDARAAN BERMOTOR DI WILAYAH KAB. BANDUNG SUDAH EMISI TAHUN 2019

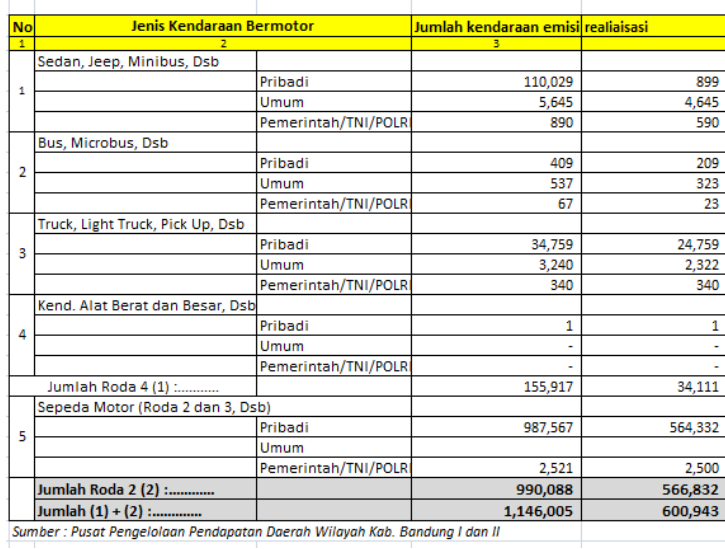

sasaran, ilihat dari tabel di bawah ini :

2. Banyaknya kendaran bermotor di Kabupaten Bandung yang belum memeriksakan emisi gas buang, berdasarkan data dari tahun 2017 sampai 2019 jumlah kendaraan hampir 55.220 kendaraan dari semua golongan yang harus memeriksakan emisi namun pada kenyataannya masih jauh dari harapan, realisasi kendaraan di kabupaten Bandung hanya 25.359 kendaraan, oleh karena itu kendaraan yang ada di kabupaten Bandung masih banyak yang belum melakukan uji petik emisi.

3. Kurangya sosialisasi dari pihak pelaksana ataupun dinas perhubungan kabupaten Bandung terhadap kendaraan yang ada di Kabupaten 
Bandung, untuk dilaksanakan uji emisi gas buang.

4. Adanya tarif retribusi uji emisi gas buang yang masih merupakan beban berat bagi sebagian masyarakat di Kabupaten Bandung. Emisi hgas buang dalam pengujian kendaraan bermotor tidak sesuai lagi dengan kondisi saat ini, mengenai retribusi untuk uji emisi, kendaraan dapat uji, pengganti cetak formulir pemeriksaan, stiker tanda lulus uji berkala dan tanda lulus uji emisi tarif retribusinya masih jauh dari harapan. Pada Tahun 2018 realisi sangat jauh dari target yang telah ditetapkan, realiasinya hanya Rp. 320.000 dari total target yang telah ditetapkan sebesar Rp. 335.125.000. Begitu juga pada tahun 2019 yang telah di targetkan sebesar Rp. 750.000.000 namun realisasinya hanya Rp. 17.150.000, padahal potensi retribusi uji pada emisi gas buang untuk dinas perhubungan Kabupaten Bandung .

5. Kesadaran Masyarakat yang masih rendah terhadap pentingnya uji emisi gas buang sehingga dianggap acuh tak acuh padahal sangat berpengaruh bagi kesehatan maupun lingkungan sekitar.

\section{TINJAUAN PUSTAKA}

Pada dasarnya banyak batasan atau definisi apa yang dimaksud dengan kebijakan publik (public policy) dalam literatur-literatur ilmu politik. Masing-masing definisi tersebut memberi penekanan yang berbeda-beda. Perbedaan ini timbul karena masing-masing ahli mempunyai latar belakang yang berbedabeda. Sementara di sisi yang lain, pendekatan dan model yang digunakan oleh para ahli pada akhirnya juga akan menentukan bagaimana kebijakan publik tersebut hendak didefinisikan (Winarno, 2007: 16). Definisi kebijakan publik yang dikemukakan oleh Thomas R. Dye (1975, dalam Syafiie) (2006: 105) menyatakan bahwa "kebijakan publik adalah apapun juga yang dipilih pemerintah, apakah mengerjakan sesuatu atau tidak mengerjakan (mendiamkan) sesuatu itu (whatever government choose to do or not to do)".

Grindle (1980), mengatakan bahwa dalam mengimplementasikan sebuah kebijakan tergantung pada content (isi) dan contextnya, dan tingkat keberhasilannya tergantung pada kondisi 3 komponen variabel sumber daya implementasi yang diperlukan. Ketiga komponen ini menyebabkan program nasional menghasilkan variasi outputs dan outcomes yang berbeda di daerah. Ketiga komponen itu adalah:

1. Contents of policy messages
a. ketersediaan dana dan sumber lain untuk melaksanakan kebijakan;
b. adanya sanksi;
c. tingkat kesukaran masalah kebijakan.

2. Kredibilitas pesan kebijakan
a. kejelasan pesan kebijakan;
b. konsistensi kebijakan;
c. frekuensi pengulangan kebijakan;
d. penerimaan pesan

3. Bentuk kebijakan
a. efficacy of the policy;
b. partisipasi masyarakat;
c. tipe kebijakan.

Selain itu Grindle juga mengatakan bahwa implementasi program ditentukan oleh konten (isi) program/policy dan konteks implementasinya, sebagai berikut :

\section{A. Content of Policy (Isi Kebijakan)}

Isi kebijakan atau program akan berpengaruh pada tingkat keberhasilan implementasi. Kebijakan kontroversial, kebijakan-kebijakan yang dipandang tidak populis, kebijakan menghendaki perubahan besar, biasanya akan mendapatkan perlawanan baik dari kelompok sasaran bahkan mungkin dari implementornya sendiri yang mungkin merasa kesulitan melaksanakan kebijakan tersebut atau merasa dirugikan. Isi kebijakan yang dapat mempengaruhi implementasi menurut Grindle adalah sebagai berikut :

\section{Kepentingan yang dipengaruhi oleh adanya program.}

Apabila kebijakan tersebut tidak menimbulkan kerugian di salah satu pihak (misalnya jenis kebijakan Redistribution menurut katagori Ripley dan Lowie), maka implementasinya akan lebih mudah karena tidak akan menimbulkan perlawanan bagi yang kepentingannya dirugikan.

2. Jenis manfaat yang akan dihasilkan. Kebijakan yang memberikan manfaat kolektif atau pada banyak orang akan lebih mudah diimplementasikan 
karena lebih mudah mendapatkan dukungan dari kelompok sasaran atau masyarakat.

3. Jangkauan perubahan yang diinginkan.

Semakin luas dan besar perubahan yang diinginkan melalui kebijakan tersebut, biasanya akan semakin sulit pula dilaksanakan. Misalnya kebijakan anti Korupsi yang telah berkali-kali dibuat oleh beberapa presiden RI dengan berbagai badan pemeriksa, tetap menjadikan Indonesia sebagai negara dengan tingkat korupsi tertinggi di dunia karena kebijakan tersebut menuntut banyak perubahan perilaku yang tidak dilaksanakan dengan konsekuen. Kredibilitas pesan kebijakan tidak terpenuhi karena isi kebijakan yang mengatur tentang adanya sangsi tidak dijalankan dengan konsisten.

4. kedudukan pengambil keputusan.

Semakin tersebar kedudukan pengambil keputusan dalam kebijakan (baik secara geografis ataupun organisatoris), akan semakin sulit pula implementasinya. Kasus demikian banyak terjadi pada kebijakankebijakan yang implementasinya melibatkan banyak instansi.

\section{Pelaksana program.}

Manakala pelaksana program memiliki kemampuan dan dukungan yang dibutuhkan oleh kebijakan, maka tingkat keberhasilannya juga akan tinggi.

Sumber daya yang disediakan.

Tersedianya sumber daya yang dibutuhkan untuk mengimplementasikan kebijakan, dengan sendirinya akan mempermudah pelaksanaannya. Sumber daya ini berupa tenaga kerja, keahlian, dana, sarana, dll.

\section{B. Context of Implementation (Konteks} Implementasi)

Konteks dimana dan oleh siapa kebijakan tersebut diimplemetasikan juga akan berpengaruh pada tingkat keberhasilannya, karena seberapapun baik dan mudahnya kebijakan dan dukungan kelompok sasaran, hasil implementasi tetap bergantung pada implementornya. Karakter dari pelaksana akan mempengaruhi tindakan-tindakan pelaksana dalam mengimplementasikan kebijakan karena pelaksana adalah individu yang tidak mungkin bebas dari kepercayaan, aspirasi dan kepentingan pribadi yang ingin mereka capai. Dalam mengimplementasikan suatu kebijakan terdapat suatu kemungkinan dari pelaksana untuk membelokkan apa yang sudah ditentukan demi kepentingan pribadinya, sehingga dapat menjauhkan tujuan dari kebijakan sebenarnya. Konteks implementasi yang berpengaruh pada keberhasilan implementasi menurut Grindle adalah sebagai berikut:

1. Kekuasaan, kepentingan dan strategi aktor yang terlibat.

Strategi, sumber dan posisi kekuasaan implementor akan menentukan tingkat keberhasilan kebijakan yang diimplentasikannya. Apabila suatu kekuatan politik merasa berkepentingan atas suatu program, maka mereka akan menyusun strategi guna memenangkan persaingan yang terjadi dalam implementasi sehingga mereka dapat menikmati outputnya.

2. Karakteristik lembaga dan penguasa.

Implementasi suatu program dapat menimbulkan konflik bagi yang kepentingan-kepentingannya

dipengaruhi. Strategi penyelesaian konflik mengenai "siapa mendapatkan apa" (misalnya penggusuran pasar tradisional menjadi supermarket) dapat menjadi petunjuk tidak langsung mengenai ciri-ciri penguasa atau lembaga yang menjadi implementor program tersebut, baik mengenai keberpihakan penguasa/lembaga pelaksana maupun mengenai gaya kepemimpinannya

3. Kepatuhan serta daya tanggap pelaksana.

Implementor harus memiliki kepekaan terhadap kebutuhan-kebutuhan kelompok sasarannya agar program yang diimplementasikan berhasil dan mendapatkan dukungan dari kelompok sasaran. 


\section{METODE PENELITIAN}

Permasalahan yang akan dikaji oleh peneliti merupakan masalah yang bersifat sosial dan dinamis. Oleh karena itu, peneliti memilih menggunakan metode penelitian kualitatif untuk menentukan cara mencari, mengumpulkan, mengolah dan menganalisis data hasil penelitian tersebut. Penelitian kualitatif ini dapat digunakan untuk memahami interaksi sosial, misalnya dengan wawancara mendalam sehingga akan ditemukan pola-pola yang jelas.

Secara teoritis format penelitian kualitatif berbeda dengan penelitian kuantitatif. Perbedaan tersebut terletak pada kesulitan dalam membuat desain penelitian kualitatif, karena pada umumnya penelitian kualitatif yang tidak berpola. Menurut Koentjaraningrat(1993 : 89) bahwa: “ format desain penelitian kualitatif terdiri dari tiga model, yaitu format deskriptif, format verifikasi, dan format grounded research.”

Penelitian ini akan menggunakan pendekatan kualitatif dengan metode analisis deskriptif sebagaimana dijelaskan Locke, Spriduso dan Silferman dalam Creswell ( 1994 : 147 ) bahwa :

Qualitative research is interpretative researh. As such the biases, values and judgment of the researches become stated explicity in the research report. Such openness is considered to be useful and positive". Artinya, aktivitas penelitian dicirikan oleh kegiatan

mengumpulkan,menggambarkan dan menafsirkan data tentang situasi yang dialami, hubungan tertentu, kegiatan, pandangan, sikap yang ditunjukan atau tentang kecenderungan yang tampak dalam proses yang sedang berlangsung, pertentangan yang meruncing, serta kerjasama yang dijalankan.

\section{PEMBAHASAN}

Wilayah Kabupaten Bandung merupakan salah satu Kabupaten di Provinsi Jawa Barat, dan lokasi penelitian yang saat ini kami lakukan adalah terhadap kendaraankendaraan yang ada di Kabupaten Bandung untuk dilakukan pemeriksaan uji emisi gas buang oleh Dinas Perhubungan dan bengkelbengkel kemitraan yang telah ditunjuk. Sehubungan dengan masih banyaknya kendaraan di wilayah Kabuapaten Bandung yang belum melaksanakan uji emisi gas buang, baik kendaraan umum maupun kendaraan pribadi, maka pihak Dinas Perhubungan selaku Pelaksana Kebijakan Peraturan Daerah nomor 15 tahun 2015 telah melakukan sosialisasi terahadap pemilik kendaraan untuk melakukan ketentuan yang telah di tetapkan Selain melakukan hal tersebut di atas, berkaitan dengan permasalahan publik yang muncul di masyarakat Kabupaten Bandung, maka pihak Dinas Perhubungan uga mengkaji ulang apakah tarif uji emisi emisi gas buang untuk kendaraan ini dirasakan terlalu memberatkan kepada masyarakat pemilik dan pengguna kendaraannya, dan kami melakukan survei dan wawancara kepada mereka baik di lokasi unit pengujian kendaraan bermotor Dinas Perhubungan Kabupaten Bandung, dilapangan dan di bengkel-bengkel tertunjuk terhadap masyarakatyang sudah dan yang belum melaksanakan uji emisi gas buang. Sesuai Kebijakan yang ada di Kabupaten Bandung bahwa setiap pemilik kendaraan bermotor pribadi wajib melakukan Pemeriksaan Emisi Gas Buang, untuk memenuhi ambang batas emisi gas buang Kendaraan bermotor, sebagai pengendalian pencemaran udara dari sumber bergerak. Peraturan Daerah Kabupaten Bandung nomor 9 tahun 2012 pasal 47 menyatakan bahwa :

[1] Pemeriksaan Emisi Gas Buang kendaraan bermotor pribadi sebagaimana dimaksud pasal sebelumnya, dilakukan sekurang-kurangnya sekali dalam setahun;

[2] Pemeriksaan emisi gas buang kendaraan bermotor pribadi dilaksanakan pada unit pengujian kendaraan bermotor, Agen Pemegang Merk [APM] dan bengkel umum yang ditunjuk sebagai Bengkel Pelaksana.

Selanjutnya pula Pada pasal 48 di katakana bahwa :

[1] Terhadap pemilik Kendaraan Bermotor milik pribadi yang melakukan pemeriksaan emisi gas buang di unit pengujian kendaraan bermotor milik pemerintah daerah aatau bengkel pelaksana dikenakan retribusi.

[2] Sebagai bukti bahwa kendaraan bermotor pribadi telah memenuhi ambang batas emisi 
gas buang diberikan Surat Keterangan dan STIKER yang dipasang pada kendaraan.

Pasal 49 berbunyi bahwa "Setiap kendaraan bermotor pribadi yang tidak memenuhi persyaratan ambang batas emisi dilarang beroperasi di jalan "Pelaksanaan Uji emisi gas buang di Kabupaten Bandung secara berkala telah dilaksanakan sesuai dengan prosedur yang telah ditetapkan, namun demikian masih belum optimal terhadap sasaran dan target kendaraan yang harus dan wajib melaksanakan uji emisi gas buang, sebagian besar memang pada kendaraan bermotor milik pribadi. Namun demikian para petugas pelaksana kebijakan telah berupaya untuk optimal melaksanakan ketentuan yang telah diamanatkan dalam Perda Kabupaten Bandung, serta harus terus berupaya adanya koordinasi dengan pihak-pihak terkait untuk dilakukan penegakan hukum di lapangan sebagai wujud pengawasan terhadap kendaraan yang beroperasi di jalanan.

Retribusi Uji Emisi Gas Buang Kendaraan

Roda dua [2] dan Roda empat [4]

Tahun 2018 dan 2019

\begin{tabular}{|c|c|c|}
\hline \multirow{2}{*}{ Kegiatan } & \multicolumn{2}{|c|}{ Tahun } \\
\cline { 2 - 3 } & 2018 & 20019 \\
\hline Target & $\mathrm{Rp}$ & $\mathrm{Rp}$ \\
& 335.125 .000 & 750.000 .000 \\
\hline Realisasi & $\mathrm{Rp} \mathrm{320.000}$ & $\mathrm{Rp} 17.150 .000$ \\
\hline Persentase & $\mathrm{Rp} 0,09 \%$ & $\mathrm{Rp} \mathrm{2,29 \%}$ \\
\hline & & \\
\hline
\end{tabular}

Sumber : UPT PKB Dinas Perhubungan Kab.

Bandung tahun 2020.

\section{KESIMPULAN}

Sesuai dengan paparan dari bab per bab di atas, penulis dapat menyimpulkan bahwa :

Kebijakan pada suatu Daerah pada umumnya dibuat bertujuan untuk menjadikan acuan, dan pijakan dalam rangka mencapai tujuan tertentu yaitu mensejahterakan masyarakat pada daerah tersebut. Tidak ada gading yang tak retak, setiap kebijakan yang di keluarkan oleh Pemerintah harus diuji keberhasilannya, setelah diimplementasikan oleh pelaksana kebijakan, apa saja kelemahan yang timbul sebagai masukan untuk dievaluasi pada kesempatan mendatang, baik mengenai target yang harus dicapai, memperbanyak sosialisasi kepada mayarakat dan aparat pelaksana kebijakan, maupun kelemahan yang ada dan harus dilakukan perubahan untuk diperbaiki.

Tentunya kebijakan di Kabupaten Bandung khususnya mengenai Implementasi penangan emisi gas buang yang saat ini masih sangat minim keberhasilannya, baik realisasi pada tahun 2018 baru mencapai 0,09 \% maupun realisasi tahun 2019 baru mencapai 2,29\%, namun demikian hal ini masih sedang dilakukan penelitian oleh penulis, yaitu dengan upaya-upaya lebih giat melakukan sosialisasi kepada target atau sasaran yang telah ditentukan yaitu para pemilik kendaraan bermotor, melakukan pengawasan bersama aparat penegak hukum di lapangan, serta mereview kembali tariff retribusi Uji emisi gas buang pada Perda Kabupaten Bandung, karena masih ada kelemahan dan kelebihan yang muncul, tetapi para pelaksana kebijakan tersebut selama ini telah melakukan upayaupaya yang terus menerus untuk menghilangkan kelemahan yang ada sehingga tujuan yang ingin dicapai sesuai dengan citacita yang telah tersurat dalam kebijakan yang telah ada dapat terwujud dengan baik.

\section{DAFTAR PUSTAKA}

Agustino, Leo. 2006. Dasar-Dasar Kebijakan Publik. Bandung : Alfabeta, cv.

Arikunto, Suharsimi. 2010. Prosedur Penelitian Suatu Pendekatan Praktek. Jakarta: PT. Rineka cipta.

Creswell, John W. 1994. Research Design Qualitative \& Quantitative Approaches. London: Sage Publication.

Gaspersz, Vincent. 1997. Manajemen Kualitas. Penerapan Konsep Kualitas Dalam Manajemen Bisnis. Terjemahan Lukman. Jakarta: Gramedia Pustaka Utama. ,2002.

Kualitas, Jakarta: Gramedia Pustaka Utama.

Grindle, Merilee. 1980. Politics and Policy Implementation in Third World. New Jersey: Princenton University Press.

Howlett, Michael, dan M. Ramsesh ( 1995 ) Studying Public Policy : Policy Cyles and Policy Subsystem.Oxford : Oxford University Press 
Riset Komunikasi. Jakarta : Kencana Prenada Media Group.

Moleong, Lexy J, 2000. Metodologi Penelitian Kualitatif. Bandung: Remaja Rosdakarya.

Napitupulu, Paimin. 2007. Pelayanan Publik dan Customer Satisfaction. PT. Alumni. Bandung.

Ndraha, Taliziduhu.2000. Kybernologi Ilmu Pemerintahan Baru, Jilid I.Jakarta : Rineka Cipta.

.2009. Faktor-Faktor yang Mempengaruhi Penegakan Hukum, Raja Grafindo Persada, Jakarta

Pressman, J. L. dan Aaron Wildavsky. 1984. Implementation: How Great Expectation in Washington are Dased in Oakland. London: California Press.

Rasyid, M. Ryaas. 1997, Makna Pemerintahan Tinjauan Dari Segi Etika Dan Kepemimpinan. Jakarta: P.T Yarsif
Watampone. 2000. Makna

\section{Electronic Books}

http://repository.uinsuska.ac.id/20191/3/3.\%20ABSTRAK .pdffrom http://digital.library.upenn.ed u/women/dehuff/taytay/taytay.html

http://repository.uinsuska.ac.id/20191/3/3.\%20ABSTRAK.pdf https://core.ac.uk/download/pdf/228969608.pd f 